\title{
Electronic Participation in Malaysia
}

\author{
Mohamad Aizi Bin Salamat ${ }^{1}$, Shahizan Bin Hassan ${ }^{2}$ \\ and Mohamad Syakiran Bin Muhammad ${ }^{3}$ \\ ${ }^{1}$ Universiti Tun Hussein Onn Malaysia (UTHM), Johor, Malaysia \\ ${ }^{2}$ Universiti Utara Malaysia (UUM) Kedah, Malaysia \\ ${ }^{3}$ Universiti Industri Selangor (UNISEL), Selangor, Malaysia
}

\begin{abstract}
This article seeks to highlight the prevalent role of electronic participation (e-participation) in the implementation of e-government (EG) and possible approaches in enhancing the application of e-government through the insertion of e-participation module. Previous case studies on e-participation cover definitions and technique of e-participation, applicable strategies to implement e-participation, and the quality of e-participation for top management decision making. Several literature in EG supports the statement that e-participation could improve the quality of public sector governance process. As a result, most developed countries implemented EG projects to enable involvement of citizens in the political decision making process through e-participation. However, this is not the case in most of the developing countries which focus more on improving public sector services rather than e-participation. Among others, there are arguments which focus on the issue of lack of citizen participation in the political process through the Internet. This is particularly true in the context of EG implementation in developing countries whereby the focus is more on e-services rather than eparticipation. Malaysian government has implemented EG, since 1997 under one of the MSC flagships, to deliver information and services in an integrated manner. Malaysian Government Portal or myGovernment performs as a single platform providing information and services related to government agencies. Despite this effort, myGovernment, as evident in other developing nations, also does not place emphasis on e-participation.
\end{abstract}

Keywords: e-government, e-participation, collaboration approach, my government portal

\section{Introduction}

The huge potential of Information and Communication Technologies (ICT) in transforming the public sector brought around the phenomenon of e-Government to nations across the world. The rapid expansion of ICT in Malaysia saw the launching of Multimedia Super Corridor (MSC), in 1996, to accelerate its entry into the Information Age. Putrajaya functions as the new seat for government and federal administrative capital becoming the centre for the introduction of the concept of
Electronic Government (EG). EG, one of the seven MSC flagships is aimed at reinventing the public sector's view of the needs of citizens and the private sector. Simultaneously, information flow and processes within the government are streamlined. Exploitation of ICT in government is expected to improve internal effectiveness and provide citizens with better information and services.

Governments worldwide have now come to realize the importance of citizen participation in democratic political

Copyright (C) 2011 Mohamad Aizi Bin Salamat, Shahizan Bin Hassan and Mohamad Syakiran Bin Muhammad. This is an open access article distributed under the Creative Commons Attribution License unported 3.0, which permits unrestricted use, distribution, and reproduction in any medium, provided that original work is properly cited. Contact author: Mohamad Aizi Bin Salamat E-maill: aizi@uthm.edu.my 
processes and are trying to re-engage them in order to strengthen the process of democracy. On the other hand, citizens in many countries are demanding for a more active role in government processes and not only to take part in the voting process (Tambouris, 2007). World Bank (2001) defines citizen participation as "the process through which stakeholder influence and share control over priority setting, policymaking, resource allocations and access to public goods and services". Since the last few years, many governments are experiencing the growth and adoption of ICTs. Following this trend, e-government should be extended to include eparticipation mechanism to get citizen's views and inputs on governments' public policy and planning. Some research referred to e-participation as eConsultation (Whyte \& Macintosh, 2002), web-based citizen input (Elgarah \& Courtney, 2002), and online public engagement (Coleman \& Gøtze, 2001). However, Betancourt (2005) claimed that ICT and EG's initiatives will not automatically enable the people to participate in EG.

E-participation serves varied objectives such as providing information to citizens, generating support among citizens, utilizing citizens' input in decision making, and inquiring for citizens' needs. It is believed that e-participation can serve to encourage two-way communication between government and citizens, educate citizens on the rationale and complexity of policy-making, legitimize government decisions, and provide opportunities for mutual learning (Coleman \& Gøtze, 2001). As a result, most developed countries have already implemented EG projects to enable citizen's involvement in the political decision making process through eparticipation.

In an attempt to provide seamless integration of information and services, Malaysian government launched myGovernment, an abbreviation for the Malaysian Government Public Service Portal. It is designed as a single gateway to information and services provided by the Government of Malaysia via the Internet.
Through myGovernment, users are linked to more than 900 government agencies websites nationwide. myGovernment is an initiative undertaken by the Malaysian Administrative Modernization and Management Planning Unit (MAMPU), a department within the Prime Minister's Department. Most of the Malaysian Government information and online services have been on the internet for a long time, and myGovernment is created to provide easy access and search for these information and services as well as answers to government related enquiries and concerns.

With this motivation in mind, we investigate an approach for assessing Malaysian government's effort in extending e-participation initiative with the current EG application. This paper is organized as follows. Section 2 presents the issues on why EG application should be extended in e-participation. Section 3 introduces the Malaysian EG initiatives. Section 4, presents the e-participation while section 5 describes the proposed approach for eparticipation initiative in Malaysia. Finally, the conclusions and future work are discussed in section 6 .

\section{Issues}

Many governments of developing countries have tried to deliver their services to citizens through ICT mechanisms. However, most implementations focused on publishing information and links to set of resources. Gupta, Kumar and Bhattacharya (2004) argued that very few of these implementations provide actual transactional service delivery through government portals. Furthermore, with non exhaustive infrastructure in term of access facility, it will complicate the delivery of a service to the people.

Malaysian government had set one major goal and several visions in ensuring successful implementation of EG. The goal is to improve the convenience, accessibility and quality of interaction with citizens and businesses; simultaneously, it will improve information flows and processes within government improving the speed and 
quality of policy, co-ordination and enforcement (MAMPU, 1997). In addition, there are five visions that are specified to achieve that goal which are to (MAMPU, 1997):

- Transform administration processes of government through usage of leading edge information technology.

- Drastically improve performance of government processes.

- Provide high quality, low cost administrative services to public and business.

- Employ multimedia technology to foster government effectiveness.

- Attract world class multimedia web shapers to Malaysia.

However, it is obvious that the goal and visions stated above contain no statements regarding the role of citizen participation in EG. With reference to UN Global EReadiness Reports (2005), the following broad definition of EG has been adopted: "The use of ICT and its application by the government for the provision of information and services to people. The aim of EG, therefore, is to provide efficient government management of information to the citizen; better service delivery to citizen; and empowerment of the people through access to information and participation in public policy decision-making". The stated visions by MAMPU entail that more focus is placed on service delivery process to the public. EG is defined, as quoted above, not only to focus on reliable service delivery but should also include public involvement in EG initiative.

Thus, a gap exists within Malaysian EG with reference to e-participation in its EG application. To ensure a more successful EG, this gap must be bridged by creating a mechanism in EG which enables people's involvement in government processes. The government needs to play a major role in determining how the citizen can participate in its EG initiative. This enables Malaysia to form a knowledgeable and active community in accordance with the progress of ICT beside the democratic process in Malaysia.

United Nation, through Global EGovernment Readiness Report 2004 and 2005, reports that Malaysia's achievement from the aspect of people participation inside the EG environment is almost static. In 2004, people participation percentage is $8 \%$, while in 2005 the percentages attained in Malaysia is still under $10 \%$. The report also highlights that Malaysia is at the fourth place after Singapore, Philippines and Indonesia.

The government recognizes the need for public involvement during the formulation of policy, schemes, and programs. However, the conventional mode of communication and information gathering mechanism makes it difficult to enable public participation in the process of decision making. The my Government portal is equipped with infrastructure and technology to facilitate such initiatives by various organizations within the government but this is still not enough to ensure a smooth running of e-participation. The development of e-participation initiatives requires public sector agencies to think well through the approach before developing an e-participation framework that can assist citizen's participation in government processes. With the background principle of democracy, public participation in government processes through ICT is an absolute necessity.

\section{Malaysian E-government}

The aim of Malaysian EG is for people in government, business and citizenry to work together for the benefit of Malaysia and all of its citizens (MAMPU, 1997). The aim calls for "reinventing [of] government" using multimedia/information technology to dramatically improve productivity and creating a collaborative environment that fosters the ongoing development of Malaysia's multimedia industry. The focus is also to ensure effective and efficient delivering of services for the people of 
Malaysia, enabling the government to become more responsive to the needs of its citizens.

The 2008 e-government readiness rankings show that Asian countries make up 20 per cent of the top 35 with Malaysia in the 34th rank; this is an improvement from year 2005 where Malaysia ranked $43^{\text {rd }}$. Singapore continues to lead the SouthEastern Asian region followed by Malaysia and Thailand. In the web measure index, Malaysia is ranked $17^{\text {th }}$ while Singapore is rank $25^{\text {th }}$, mostly due to the strength of Malaysia's three ministries' websites, namely: Social Welfare, Labour and Finance (United Nations, 2008). Malaysia has enhanced the websites of the three ministries by using multimedia tools (both audio and video). In addition, these sites encourage citizen e-participation and provide the citizens with downloadable forms. The Ministry of Labour has a formal time frame by which to respond to online queries and e-mails and the Ministry of Social Welfare has the ability to respond to its citizens via e-mail.

Malaysian EG identifies the services provided by government and the spectrum of multimedia application that will help deliver these services according to the objectives of EG vision. The landscape of application is grouped into three categories: Public/business to government, intra agency and inter agency. The main portal for Malaysian citizen or nonMalaysian citizen to refer to is myGovernment portal.

\section{My Government Portal}

My Government is the government's initiative to improve service delivery introduced in 2003 by the Malaysian Administrative Modernisation and Management Planning Unit (MAMPU) under the Prime Minister's Department. My Government portal won top prize in the public sector award category in the 2008 Global ICT Awards. This portal begins its operation in 2005 with its main objective to enable the public and business community to acquire online information and government services that can be obtained through the local service centre. Services offered are prime news display, event calendar, job vacancy, tender notice, advertisement, announcement, public complaint and form downloads. Through this portal, dealings with agency become more efficient, easy and the public can reduce time spent at the physical counter.

The my Government portal contains six (6) components (MAMPU, 2007):

1) My Home is where users register with my Government portal and personalized information display according to their preferences. Through this personalization, consumers are able to accept message updates, upload documents, and view online service status offered through my Government and web agency sites link.

2) Message's Centre which acts as a communication centre facilitating exchanging of messages among users and my Government administrators.

3) E-Community Centre which provides community oriented services such as poll, service or information subscription, advertising and general questions. Ecommunity Centre is a component that seeks for citizen involvement in Malaysian government. However, based on the current status, only poll mechanism is successfully running. The average number of people involved in poll is just 1000 people per poll. This brings a greater need in an e-participation platform to ensure citizens' involvement in government processes.

4) E-Business Centre supplies all the downloadable forms and online interactive services by public sector agencies in my Government.

5) Administrative Centre which enables myGovernment administrator to manage the portal.

6) Content Delivery Centre which provides infrastructure in managing myGovernment content such as search engine facility and myGovernment content broadcasting through Internet. The most popular 
services on the MyGovernment portal are accessing government tenders, checking employment prospects in government agencies, renewing a driving licence, paying traffic summons, registering a business, and filing of income tax return electronically.

The portal links more than 900 public sector websites at federal, state and local levels, as well as delivering government services to citizens. Currently, 30 per cent of agencies provide their services through myGovernment portal. UN researchers in the annual Global E-Government Report evaluate criteria such as multi language, website personalization, feedback mechanism, workable support links and navigation within tolerance. The number of visitors to the portal has increased almost threefold in two years with a number of 6.5 million visitors as at May 15 2008, according to MAMPU. The multi-channel service typified by myGovernment is being continued in the Ninth Malaysian Plan 2006-2010 and further improvement for the convenience of users is being promoted.

As mentioned above, E-community Center is a component that encourages citizens to get involved in Malaysian political process. However, based on the current status, only poll mechanism is successfully run indicating a low level of citizens' involvement in e-government. Based on the statistic, average number of people who are involved in poll is only 1000 people per poll. Thus, it is clear that Malaysian government badly needs an e-participation platform to improvise citizen involvement in e-government process. Currently, this Ecommunity Center has added a few mechanism to extent citizen involvement through e-government initiatives which are survey, feedback and enquiry and public complaint.

\section{E-participation}

E-participation is seen to be an essential part of e-government. Many case studies were conducted previously on eparticipation which includes definition and technique of e-participation, applicable strategies to implement e-participation, quality of e-participation for top management decision making and others. Some literature on EG supports the statement that e-participation could improve the quality of public sector governance process (Verma, Singh \& Misra, 2007). According to Scherer, Schneider and Wimmer (2008), EG is a well-established field in research and practice, while eparticipation trails behind with only a low number of programs and strategies at the moment. It also reflects ideas of the concept of good governance in term of ethical behaviour, governance process and others.

Citizen participation has been discussed widely especially in the field of political sciences and administration. It is often defined as a citizen action that influences or seeks to influence policy decisions (Nagel, 1987). Meanwhile Zimmerman (1986) claims that citizen participation is an action that incorporates the demands and values of citizens into public administration services. Citizen participation can be categorized into 2 parts; political participation and administration participation (Zimmerman, 1986). Political participation relates to citizen involvement in election in political proceeding while administration participation relates to citizens' participation the management processes of government agencies.

E-participation has gained rising importance within the information society. In general, participation means "to take part or to be involved in it" (Chamber 21 ${ }^{\text {st }}$ Century Dictionary, 1996, p. 1005). With the exploitation of ICT, participation will be more of electronic nature known as eparticipation. Macintosh (2006) describes e-participation as "ICT-supported participation in processes involved in government and governance. Processes may concern administration, decision-making, service delivery, and policy making". It transforms relations between citizen and decision-makers, and those activities are expected to help renew the representative model of democracy. Meanwhile, according to Europe's Information Society Thematic 
Portal ( "e-participation is about reconnecting ordinary people with politics and policy-making and making the decision - making process easier to understand and follow through the use of new Information and Communication Technologies (ICTs)".

However, based on OECD report, eparticipation is a term used to refer to the use of information and communication technologies (ICTs) in supporting information, consultation and participation. E-participation is, to a certain extent, the same as marketing activities and CRM (Customer Relationship Management) in the private sector (OECD, 2001). The definition is supported by United Nation e-participation index where e-participation is defined as ICT-enabled "participatory, inclusive, deliberative process of decision making", including the increased supply of information (einformation), enhanced consultation (econsultation) and the willingness of government to take into account the einput of citizens into the decision making process and subsequently inform citizens on what decisions have been taken based on the consultation processes with the framework of G2C and G2B interaction (edecision-making) that may lead to increased input of citizens in decision making (United Nation, 2008).

Through successful e-participation implementation, government processes will be more transparent. This argument is supported by Hacker and Van Dijk (2000) which emphasize on e-participation's role in improving the transparency of governmental activities: "e-participation has the potential to establish more transparency in government by allowing citizens to use new channels of influence which reduces barriers to public participation in policy making".

\section{E-participation Approach}

Multi-perspective approach is one of the eparticipation approaches used in developing an e-participation initiative.

\section{The Politics and Organization Perspective}

It is assumed that the involvement of citizens in the process of decision-making and implementation will make the public sector agencies more responsive and effective. As such, the government needs to find ways in eliminating the gap between citizens and government. E-participation could be an effective tool for collecting or disseminating information and knowledge from citizen, experts, and stakeholders.

However, there are potential problems that could prevent the smooth process of implementing e-participation for a more open, transparent and inclusive public. Also, stronger involvement of citizens and more responsive and effective performance should be looked. Currently, citizen participation through the Internet plays only a marginal role in the political process (Koulolias, 2007). Government should focus on the potentials and impacts of the ICT (Internet) for two-way-communication in e-participation. The authorities should pay more attention in ensuring access to all citizens to the e-participation. The access to the Internet is a key barrier for eparticipation success. It should be seen as a responsibility of the government to overcome this barrier.

\section{The Communication and Interaction Perspective}

This perspective focuses more on the citizen participation process. This means that design and implementation of process are always studied in relation to the use context. Authorities should focus on interaction and communication in both design processes and in the designed system. Developer should emphasize on designing systems to contribute to quality in use by developing techniques for users to participate in the design process. The participation processes in the design of information systems will lead to improved quality in use (Myers et al., 1997). Interactions perspectives are at: 
1) both user levels were focusing on the support of them in order to make them capable to participate and ability to let users interact and communicate.

2) An organizational level to develop techniques and processes in order for different stakeholders to participate.

\section{The Technology and Infrastructure Perspective}

This perspective takes into consideration system applications such as voting systems, poll, debate system, forums, people voice systems and others. Some applications are dependent on infrastructure either physical infrastructure or conceptual infrastructure. Infrastructure is an important aspect of concern because eparticipation needs a suitable infrastructure for effective implementation. The development and implementation of eparticipation system and the infrastructures are co-dependent. The main issue in e-participation is citizen involvement in the new applications. In order to capture the most effective eparticipation, system developer has to consider the successful variables of eparticipation.

\section{Malaysian E-participation Approach}

Governments expanded their eparticipation initiatives through certain processes determined by their management. As suggested in this paper, Malaysian government should expand eparticipation initiative through the knowledge process approach. Creating and sharing the idea or information, is the most important element in this e-participation initiative. Beside strengthening relationship and exchanging ideas or information, it can also improve the decision making process in government sector. Technical systems have been developed as a foundation for eparticipation. To provide facilities for eparticipation, organization must look at the future technical site as well as information environment such as human interaction policies, and information transfer process. Understanding the context in depth is also important which includes pressures from the outside environment such as communities, government and stakeholders (Devenport, 1997).

E-participation can be assumed as a mechanism that allows citizen in a country to create a community for collecting information and sharing the knowledge they know to increase the quality of government process. Based on researchers' readings and opinions, e-participation initiative in Malaysian environment should be carried out through three main resources: citizen, process and technology. These three resources must play their role together to make e-participation effective as depicted in Fig 1.

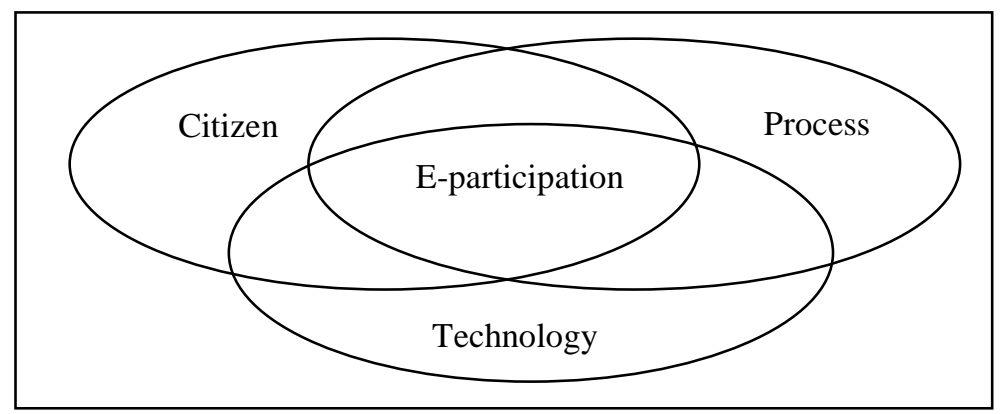

Fig 1. Keys for Realization of E-participation

\section{Citizen}

Citizen does not play a role in managing the information, but the government can structure policies and training to assist the interaction through e-participation application. E-participation initiative can include design that fosters professional 
cooperation by actively involving citizen at every level of society in sharing information and knowledge of their opinion, idea or comment and suggestion for improvement. Looking at governments with developed e-participation initiative in their country, it is proven that cooperation between citizen and government as one group will produce an excellent working style, more effective and improved democracy process. This working group will create a relationship, trust and expertise between citizen and government. As an outcome of this resource, it will encourage development and facilities for communities of practice (CoP) element.

\section{Process}

Management process in government organization, be it formal or informal, requires a flow of information. Most citizens do not realize the existence of such process in some organization. The element of this process is in determining the ways of how to convey information by the government to the people and vice-versa. It also forms as a connection between technologies with citizen and becomes a resource to sustain the relationship between citizen and government. Many methods developed by other countries can be deployed into the Malaysian environment. This process will play an important role because people will see whether or not information delivered is accepted by the government and would further show whether the government is transparent or not. It should not only act as the relationship among government and people, but also to help establish ties between the people. The processes will help to produce the information needed by the government and to share the information for benefits.

\section{Technology}

Technology functions not only as a centre of repository of resources and not only as reference in using e-participation. Technology also acts as a tool and requires contribution from the citizen to ensure a more effective government process. Effective technology in designing e- participation initiative will create an archive for the targeted citizen in exchanging information with the government. Several countries have employed mobile technology as their process to make e-participation more successful. Internet with web based system application is the best approach for a beginning in the running of e-participation within the Malaysian environment.

After Multi-perspective approach and key for realization of e-participation have been explored, one collaborative approach for Malaysian e-participation initiative has been developed. Researcher suggested the collaboration approach is shown in Figure 2. The approach has two important elements that are dependent on one another: Information Acquisition and Information Dissemination.

Information acquisition is described as the acceptance of information submitted to government by citizen i.e. Communities, NGOs, Individual and Interest Groups while, information dissemination is described as the process of delivering information to particular users. The main processes in this element are knowledge collection and storage to be disseminated to people. Information will be gathered from outside or inside sources and will be stored in the repository. The combination of these elements will create and establish e-participation process. Three perspectives (people, process and technology) are the controlling mechanism to establish a successful e-participation initiative.

In brief, knowledge process approach in eparticipation concept is an approach that requires commitment from every stakeholder for smooth and effective running of e-participation. There is a crucial need in understanding how to integrate this collaboration approach within Malaysian environment. Conversely, an organization investing in new technology without first understanding the organization and their patents, will not achieve potential and profits from the investment made (Petrides \& Nodine, 2003). 


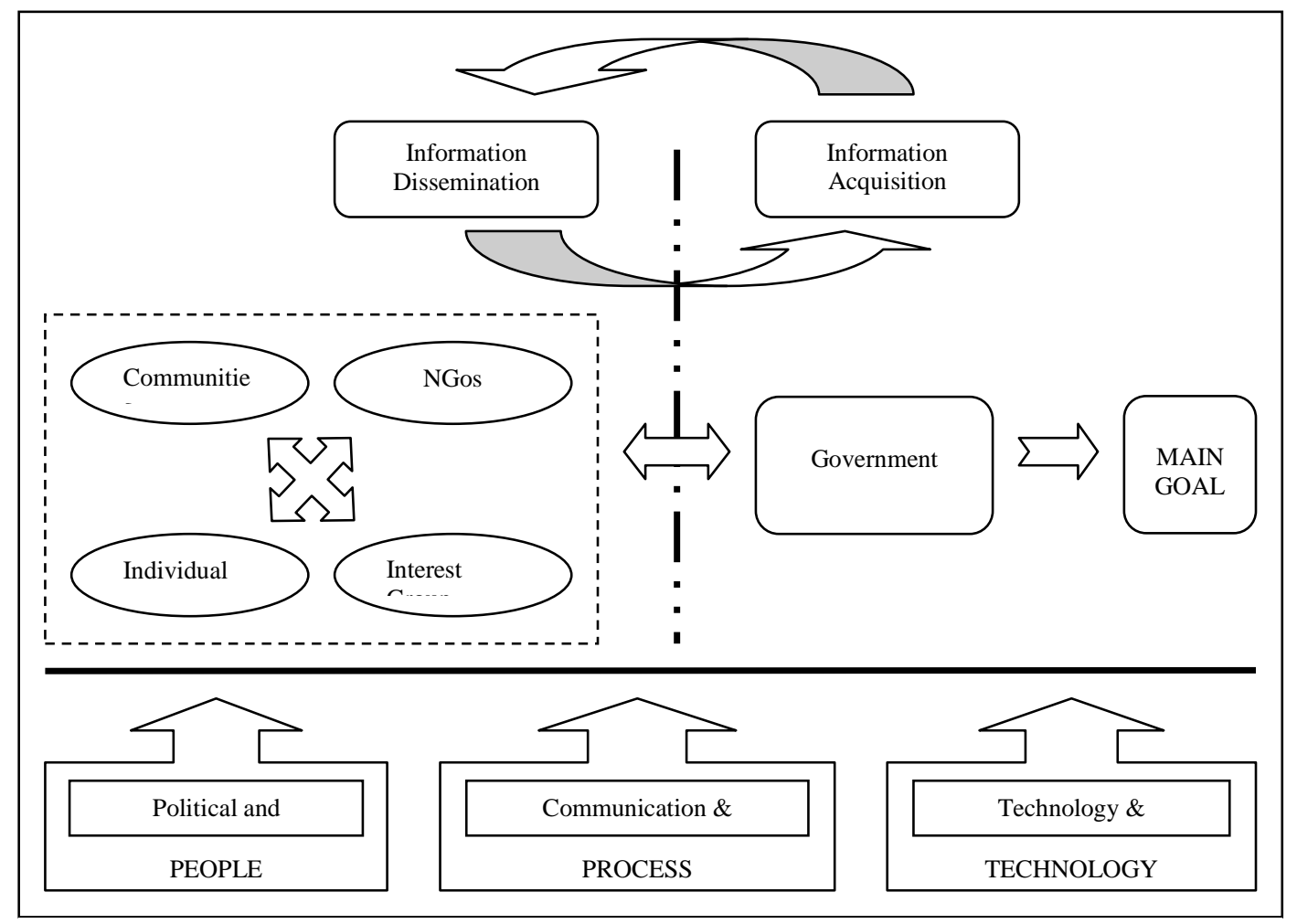

Fig 2. Collaboration Approach for Malaysian E-participation Initiative

\section{Conclusion and Future Work}

With the help of ICT, e-participation will increase citizens' input to government and citizen's participation must come together with ICT support. It can be concluded that work is needed on both sides (citizen and government) to enable wider interaction and benefits. Although e-participation could increase the level of transparency, participatory decision making and accountability, the government faces huge challenges to implement and facilitate it.

This collaborative approach is a basic foundation for the development eparticipation framework in the next phase. In ensuring successful implementation of eparticipation, there is a need for awareness of some factors such as the process, the level of participation, the communication platform, the role of facilitation and consultation and the role of ICT (Jansky \& Juhal 2006). These factors should be scrutinized to ensure successful eparticipation initiative. The result should clearly describe how citizen participation fits into government process. This approach can be integrated into an e- participation framework and can be used for participatory techniques and strategy with ICT tools.

The process of e-participation should be adopted concurrently with a system whereby people from different background have an equal opportunity and equal access to participate in the government process. This is necessary to ensure that a larger number of people participate in the movement of e-government. Consequently, this will realize the vision of 'reinventing government' where Government-to-Citizen and Citizen-to-Government communication is freely accessible under main portal (mygovernment portal).

\section{References}

Betancourt, V. (2006). "E-government: An Opportunity for Citizen Participation in the Era of Digital Development," Association for Progressive Communications (APC). [Online], [Retrieved October 11, 2008], http://www.apc.org/ en/news/all/ world/e-government-opportunity-citizenparticipation-era 
Coleman, S. \& Gøtze, J. (2001). "Bowling Together: Online Public Engagement in Policy Deliberation," United Nations Educational, Scientific and Cultural Organization. [Online], [Retrieved October 11 , 2008], http://portal.unesco.org/ci/en/ev.php-

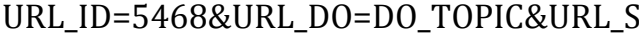
ECTION=201.html

Davenport, T. H. (1997). "Ten Principles of Knowledge Management and Four Case Studies," Knowledge and Process Management, 4(3). 187-208.

Elgarah, W. \& Courtney, J. F. (2002). "Enhancing the G2C Relationship through New Channels of Communication: Webbased Citizen Input," Proceedings of the 8th Americas Conference on Information Systems [CD Proceedings].

"eParticipation," Europe's Information Society Thematic Portal. [Online], [Retrieved July 23, 2008], http://ec.europa.eu/information_society/a ctivities/egovernment/policy/eparticipatio n/index_en.htm

Gupta, M. P., Kumar, P. \& Bhattacharya, J. (2004). 'Government Online Opportunities \& Challenges,' Tata Mcgraw Hill Publishing, New Delhi.

Hacker, K. L. \& Van Dijk, J. (2000). 'Digital Democracy: Issues of Theory and Practice,' SAGE Publications: London.

Jansky, L. \& Uitto, J, I. (2005). "Enhancing Participation and Governance in Water Resources Management: Conventional Approaches and Information Technology," United Nations University Press: Tokyo.

Koulolias, V. (2007). "Interview with Vasilis, Executive Director of Gov2U," egovblog: The future of governments. [Online], [Retrieved October 12, 2008], http://www.egovblog.com/2007/03/21/i nterview-with-vasilis-koulolias-executivedirector-of-gov $2 \mathrm{u}$ /

Macintosh, A. (2006). 'Characterizing eParticipation in Policy-making,' Proceedings of the 37th Hawaii
International Conference on System Sciences (HICSS"04). ISBN: 0-7695-2056-1, 117-126

MAMPU (1997). 'Electronic Government Blueprint for Implementation,' Malaysian Administrative Modernisation and Management Planning Unit: Kuala Lumpur.

MAMPU (2007). 'Garis Panduan Portal Mygovernment Dan Laman Web/Portal Agensi-Agensi Sektor Awam,' Seminar Personel ICT SektorAwam

Myers, B. L., Kappelman, L. A. \& Prybutok, V. R. (1997). "A Comprehensive Model for Assessing the Quality and Productivity of the Information Systems Function," Information Resources Management Journal, 10(1). 4-33.

Nagel, J. (1987). 'Participation,' Prentice Hall: New Jersey.

OECD (2001). 'Citizens as Partners: Information, Consultation and Public Participation in Policy-Making,' OECD: Paris.

Petrides, L. A. \& Nodine, T. R. (2003). "Knowledge Management In Education: Defining the Landscape," Institute for the Study of Knowledge Management in Education: California

Robinson, M. \& Davidson, G. W. (1996). 'Chambers 21st Century Dictionary,' Chamber publication

Scherer, S., Schneider, C., Wimmer, M. A. \& Shaddock, J. (2008). "Studying eParticipation in Government Innovation Programmes: Lessons from a Survey," Proceedings of the 21st Bled eConference: Overcoming through Multi-Channel interaction, 15-18 June 2008, 483-497.

Tambouris, E., Liotas, N., Kaliviotis, D. \& Tarabanis, K. (2007). "A Framework for Scoping eParticipation," The Proceedings of the 8th Annual International Digital Government Research Conference, ISBN: 159593-599-1. 
11 Journal of e-Government Studies and Best Practices

United Nations (2008). e-Government Survey 2008: From e-Government to Connected Governance, United Nations: New York.

United Nations (2004). Global EGovernment Readiness Report 2004: Towards Access For Opportunity, United Nations: New York.

United Nation (2005). Global Egovernment Readiness Report 2005: From E-government to E-inclusion, United Nations: New York.

Verma, N., Singh, S. \& Misra, D. P. (2007). "Citizen Participation in the Process of ICT
Enabled Governance: A Case Study," Proceeding of 1st International Conference on Theory and Practise of electronic governance (ICEGOV). ISBN:978-1-59593822-0, 10-13 December 2007, 371-379.

Whyte, A. \& Macintosh, A. (2002). "Analysis and Evaluation of E-Consultations," $e$ Service Journal, 2(1). 9-34.

World Bank, (2001). Poverty Reduction Source Book, Vol. 1, World Bank.

Zimmerman, J. (1986). 'Populism Revisited,' State Government, 58, 172-178. 